\title{
Correction: The negative influences of exam- oriented education on Chinese high school students: backwash from classroom to child
}

Robert Kirkpatrick ${ }^{*}$ and Yuebing Zang

* Correspondence: Itaeditor@gmail.
com
, , ,

\section{Correction}

During the drafting of the original article (Kirkpatrick and Zang 2011), neither author noticed that a citation was incorrect, with only part of the citation given in quotation marks, and the remainder appearing as if it were paraphrased.

The original, incorrect, citation: (Kirkpatrick and Zang 2011), p.39.

By the time a student reaches the age of 15 , he or she has spent four or five hours a day, for over the course of nine years learning to write a minimum of 3,000 characters. Stephen Wong (2009) wrote in the Asia Times, "It's possible that no other country has as many exams as China." From school admissions and job recruitment to promotion in the civil service, exams are an inseparable part of Chinese life. Studies suggest there are currently existing 200 governmentorganized nationwide examinations and nearly 40 million people appear for them each year, perhaps more, if local-level tests are included in the list.

Correction

From age 6 to 15 students have to master around 3000 logograms (hanzi, Chinese characters), a formidable task. Stephen Wong (2009) wrote in the Asia Times, "It's possible that no other country has as many exams as China. From school admissions and job recruitment to promotion in the civil service, exams are an inseparable part of Chinese life". Studies suggest there are currently "200 governmentorganized nationwide examinations, and nearly 40 million people" appear for them each year, perhaps more, "if local-level tests are included on the list"(Wong, 2009).

Further, on the reference page the author, year and URL were correct, but the month and title of the article were incorrect.

(Kirkpatrick and Zang 2011), p.44.

Original reference: Wong, S. (2009), November 25. In China, an easy route to academic glory. Asia Times.

Correction: Wong, S. (2009), August 22. No stopping China's cheaters. Asia Times. 
References

Kirkpatrick, R., \& Zang, Y. (2011). The negative influences exam-oriented education on Chinese high school students: backwash from classroom to child. Language Testing in Asia, 1, 36-45.

Wong, S. (2009). No stopping China's cheaters. In Asia Times. Retrieved from http://www.atimes.com/atimes/China/ KH22Ad01.html.

doi:10.1186/2229-0443-4-2

Cite this article as: Kirkpatrick and Zang: Correction: The negative influences of exam-oriented education on Chinese high school students: backwash from classroom to child. Language Testing in Asia 2014 4:2.

Submit your manuscript to a SpringerOpen ${ }^{\odot}$ journal and benefit from:

- Convenient online submission

- Rigorous peer review

- Immediate publication on acceptance

- Open access: articles freely available online

- High visibility within the field

- Retaining the copyright to your article

Submit your next manuscript at $>$ springeropen.com 